\title{
Analisis Kebijakan Lalu Lintas Pada Kawasan Zero Point Kota Manado
}

\author{
$1^{\text {st }}$ Jetty E. H. Mokat \\ FIS UNIMA \\ Prodi ilmu administrasi negara \\ Tondano, Indonesia \\ jettymokat@unima.ac.id \\ $2^{\text {nd }} G$. H. Tumbel \\ FIS UNIMA \\ Prodi ilmu administrasi negara \\ Tondano, Indonesia \\ goinpeacetumbel@unima.ac.id \\ $3^{\text {rd }}$ Gregorio Gerald Luntas \\ FIS UNIMA \\ Prodi ilmu administrasi negara \\ Tondano, Indonesia \\ gregoriogluntas@gmail.com
}

Abstrak - Penelitian ini bertujuan untuk menganalisis kebijakan Lalu Lintas Pada Kawasan Zero Point Kota Manado. Penelitian ini menggunakan pendekatan kualitatif, dengan teknik pengumpulan data yaitu: observasi, dokumentasi, dan wawancara. Sumber data adalah: sopir angkutan kota, Kepala Bidang Lalu Lintas dan Angkutan Jalan, Kepala Seksi Bidang Lalu Lintas Angkutan Jalan, Kepala Bagian Umum dan kepegawaian. Data dianalisis secara deskriptif kualitatif. 1). Peramalan Masa Depan Kebijakan, 2). Pemantauan Hasil Kebijakan, 3). Evaluasi Kinerja Kebijakan, 4). Teknis. Hasil penelitian menunjukkan bahwa terdapat pelanggaran Lalu Lintas di Kawasan Zero Point Kota Manado, yaitu: 1). Belum dilakukan sosialisasi pada msyarakat tentang fungsi pelintasan yang disediakan pemerintaah Kota Manado, 2). Belum terdapat komitmen yang kuat dari petugas yang ditugasi mengawasi kawasan Zero point, 3). Pdinas Perhubungan belum memberikan sanksi yang tegas dan nyata berdasar struktur birokrasi pada dinas Perhubungan Kota Manado, 4). Terdapat kesukaran teknis yang dihadapi implementer kebijakan. Untuk itu disarankan sebaiknya: 1). Perlu dilakukan sosialisasi agar masyarakat mengetahui dan memahami fungsi pelintasan yang disediakan pemerintaah Kota Manado, 2). Dibutuhkan komitmen yang kuat dari petugas yang ditugasi mengawasi kawasan Zero point, 3). sanksi deberikan sesuai struktur birokrasi yang ada dalam dinas Perhubungan Kota Manado, 4). Kesukaran teknis yang dihadapi implementer sebaiknya diatasi oleh pejabat pelaksana tugas.

Kata kunci: Analisis Implementasi Kebijakan Lalu Lintas, Manado 


\section{PENDAHULUAN}

Lalu lintas pada umumnya merupakan suatu aktivitas yang melibatkan tiga komponen yaitu masyarakat sebagai pengguna, kendaraan, dan tempat. Lalu lintas dan angkutan berperan untuk mendukung pembangunan dalam rangka memajukan kesejahteraan masyarakat. UndangUndang No 22 Tahun 2009 Tentang LLAJ dalam Pasal 1 Angka 32: lalu lintas merupakan suatu keadaan berlalu lintas yang berlangsung secara teratur sesuai dengan hak dan kewajiban setiap pengguna jalan. UU No 22 tahun 2009 pada dasarnya mempengaruhi peran penting dalam menunjang pelanggaran berlalu lintas. Hal ini sering melibatkan masyarakat maupun pemerintah selaku penyelenggara Negara [6].

Pemerintah Kota Manado juga membuat peraturan untuk membantu proses ketertiban arus lalu lintas, yaitu dalam Perwako No 53 Tahun 2016 tentang Kedudukan Susunan Organisasi, Tugas dan Fungsi Serta Tata Kerja Dinas Perhubungan, yang dalam pasal $13 \mathrm{~g}$ : Melaksanakan pembinaan keteriban dan disiplin lalu lintas di jalan, dan pasal 23 i: Melaksanakan operasi dan penertiban terhadap kendaraankendaraan yang parkir dan atau mengganggu kelancaran arus lalu lintas di wilayah area parkir. [8]
Dalam berlalu lintas dibutuhkan manajemen lalu lintas yang berhubungan dengan kegiatan perencanaan, pengendalian, pengawasan, dan pengaturan lalu lintas. Dalam hal ini manajemen

lalu lintas bertujuan untuk a. ketertiban, b. keamanan, c. keselamatan, d. kelancaran arus lalu lintas, dan dipraktekan antara lain dengan usaha peningkatan ruas jalan, persimpangan dan jaringan jalan, juga dilakukan pemberian prioritas bagi jenis kendaraan atau pemakai jalan tertentu serta penetapan sirkulasi lalu lintas, larangan, dan perintah bagi pemakai jalan.

Sistem transportasi yang diharapkan pada umumnya adalah bila waktu tempuh perjalanan cukup efektif dan efisien, pelayanan yang cukup aman, tidak macet dan tentunya terhindar dari kecelakaan. Untuk mencapai kondisi yang baik ini tidak mudah karena tergantung pada beberapa faktor yang menentukan, antara lain, yaitu: a). kondisi sarana kendaraan, b). kondisi prasarana (jalan) serta sistem jaringannya, c). kondisi jalan atau terotoar d). sikap atau mental pengemudi/ pemakai jalan. Kemudian dilihat dari perencanaannya serta pelaksanaan transportasi kota, maka dalam hal ini sangat penting untuk memahami teknik berlalu lintas yang meliputi: a). kapasitas jalan, b). karakteristik volume lalu lintas, c). mobil penumpang, dan d). tujuan berlalu lintas yang diharapkan. Oleh sebab itu perlu ada tindakan 
dari pemerintah untuk lebih memperhatikan lagi dampak pelanggaran-pelanggaran lalu lintas yang dapat menyebabkan sistem transportasi tidak berjalan dengan baik.

Kemacetan yang terjadi di kota-kota besar di Indonesia akan terus meningkat seiring dengan pertumbuhan ekonomi dan pemekaran kota. Kemacetan tidak akan pernah teratasi jika hanya sering diminimalisir secara sering dilakukan dengan pola teknis pelaksanaan yang sama, terlebih jika yang diatasi adalah masalah yang lama dengan solusi atau cara yang sama, hal ini biasanya tidak menyentuh akar permasalahan yang sebenarnya dan jika hal ini terus menerus terjadi, maka apapun yang dilakukan pemerintah tidak akan memberi solusi dalam mengatasi masalah kemacetan atau pelanggaranpelanggaran lalu lintas yang sering terjadi. Maka sangat diperlukan proses evaluasi lalu lintas yang dapat meninjau teknis pelaksanaan, kinerja, maupun teknis perlengkapan lalu lintas.

Kota Manado merupakan salah satu kota yang memiliki masalah kemacetan yang tinggi dalam lalu lintas (SindoNews.com). Hal ini dapat berpengaruh dalam manajemen lalu lintas, khususnya dibeberapa titik di Kota Manado, berdasarkan data yang didapat salah satu titik yang sering terjadi kemacetan dan pada umumnya rawan terjadi pelanggaran lalu lintas, ditemukan pada kawasan Zero Point Kota Manado.
Tugu Zero Point Kota Manado terletak di tengah persimpangan jalan protokol, jalan Sam Ratulangi dan jalan Jendral Sudirman. Posisi tugu yang berada tepat di tengah jalan yang sangat ramai dengan kendaraan-kendaraan lalu lintas dan masyarakat secara umum ini adalah tugu yang dibangun sebagai penanda titik nol kota, dimana semua ukuran jarak ke berbagai tempat di Kota Manado dan sekitarnya bertemu.

Pelanggaran berlalu lintas menjadi penyebab utama lokasi tersebut sering dikatakan rawan macet atau rawan terjadinya pelanggaran lalu lintas, ditinjau dari beberapa faktor yang mempengaruhi pelanggaran lalu lintas di kawasan zero point antara lain, faktor implementasinya atau pelaksanaan, dalam hal ini sistem manajemen lalu lintas di kawasan zero point sangat penting untuk mengatur arus lalu lintas yang aman dan lancar bagi masyarakat, kemudian dari faktor teknis perlengkapan menjadi kebutuhan yang diperlukan dilapangan sehingga dapat membantu masyarakat dan kendaraan secara umum guna untuk menjadi petunjuk jalan, dan sarana prasarana lalu lintas. Faktor kinerja, merupakan aktivitas lapangan bagi petugas Polisi LLAJ untuk mengawasi sistem lalu lintas dengan tupoksi yang telah ditetapkan, sehingga hal ini dapat sekaligus mengontrol situasi dan kondisi lapangan. 
Secara umum kebijakan digunakan untuk menunjukan atau menetapkan pilihan terpenting untuk mempererat hubungan sosial dalam kehidupan bermasyarakat, baik dalam kehidupan organisasi kepemerintahan maupun privat. Menurut Nugroho (2008), bahwa Kebijakan Publik adalah keputusan yang dibuat oleh negara, khususnya pemerintah, sebagai strategi untuk merealisasikan tujuan negara yang bersangkutan untuk mengantar masyarakat menuju pada masyarakat yang dicita-citakan. kebijakan sangat dibutuhkan dalam suatu sistem negara. Suatu kebijakan artinya membentuk suatu kesepakatan bersama sebagai upaya untuk memperoleh hasil yang telah diprioritaskan [2].

Hal ini menjadi menarik untuk dibahas sehingga peneliti melakukan penelitian dengan judul: Analisis Implementasi Kebijakan Lalu Lintas Pada Kawasan Zero Point Kota Manado

Berdasarkan uraian latar belakang permasalahan tersebut maka tujuan dari penelitian ini adalah Mendeskripsi Proses kebijakan lalu lintas di kawasan Zero Point Kota Manado

\section{METODE PENELITIAN}

Metode yang digunakan dalam penelitian ini adalah kualitatif. karena dengan metode kualitatif bersifat menekankan pada makna yang dicari, pengungkapan makna di balik fenomena atau peristiwa yang muncul di dalam penelitian, dengan tujuan agar masalah yang akan dikaji lebih bersifat komprehensif, mendalam, alamiah, dan apa adanya serta tanpa banyak campur tangan dari peneliti terhadap fakta yang didapat.

Fokus penelitian yaitu Analisis Kebijakan mengacu pada masalah ketertiban lalu lintas yang ditinjau dari faktor implementasi, teknis, kinerja, maupun mengevaluasi kebijakan yang ada di kawasan Zero Point Kota Manado. Dengan menggunakan Konsep Analisis Kebijakan menurut William Dunn/ Patton dan Savicky [3].

\section{indikator:}
a. Peramalan Masa Depan Kebijakan,
b. Pemantauan Hasil Kebijakan,
c. Evaluasi Kinerja Kebijakan,
d. Teknis

\section{lokasi penelitian dilakukan di kawasan Zero Point Kota Manado dan Dinas} Perhubungan Kota Manado. Informan dipilih secara purposif (purposive sampling). Hal ini dimaksudkan untuk memilih informan yang benar-benar relevan dengan masalah penelitian sehingga data yang didapat dipergunakan untuk membangun kesimpulan. Cara memperoleh data yaitu setelah mewawancarai informan pertama peneliti meminta untuk diarahkan kepada orang lain yang dapat memberikan informasi, dan setelah itu informan kedua juga diminta untuk mengarahkan kepada orang lain yang menjadi informan selanjutnya dan seterusnya sampai menemukan data yang sesuai. Cara ini lazim disebut dengan "snowball sampling" yang 
dilakukan secara serial dan berurutan. Ada pun yang menjadi informan adalah sopir angkutan kota, karyawan swasta, dan Pegawai Dinas Perhubungan Kota Manado bidang LLAJ dan kasubag Umum/ Kepegawaian.

Data sekunder berasal dari sumber bacaan artikel, regulasi dan sebagainya.

Teknik untuk mengumpulkan data melalui observasi langsung, wawancara dengan informan, dan dokuentasi di lokasi penelitian.

\section{HASIL DAN PEMBAHASAN}

Permasalahan lalu lintas biasanya tumbuh lebih cepat dari upaya untuk melakukan pemecahan permasalahan transportasi sehingga mengakibatkan permasalahan menjadi bertambah parah dengan berjalannya waktu. Masalah Ketertiban Berlalu lintas di jalan raya menjadi tanggung jawab bersama, bukan hanya pihak kepolisian tetapi seluruh pengguna jalan, oleh sebab itu seluruh pengguna jalan memiliki kewajiban untuk mentaati peraturan berlalu lintas. Terkait masalah berlalu lintas peraturanperaturan di jalan raya yang seharusnya dipatuhi yaitu tidak menerobos lampu merah, menggunakan helm setiap berkendaraan roda dua, memiliki surat pengendara yang lengkap. tetapi adapun pelanggaran lalu lintas yang ditemukan yaitu, kendaraan umum yang sering kedapatan melakukan parkir liar, serta masyarakat penjalan kaki yang tidak tertib melintasi jalan. Hal ini tentunya yang dapat mengganggu kelancaran arus lalu lintas di setiap titik tertentu di jalan raya.

Oleh karena itu, dibutuhkan manajemen lalu lintas sebagai suatu kebijakan yang telah ditetapkan untuk dilaksanakan agar dapat mencegah permasalahan yang terjadi dalam arus lalu lintas disetiap jalan raya.

Suatu kebijakan sangat penting dalam proses pelaksanaan. Nugroho (2017), bahwa Kebijakan Publik adalah keputusan yang dibuat oleh negara, khususnya pemerintah, sebagai strategi untuk merealisasikan tujuan negara yang bersangkutan untuk mengantar masyarakat menuju pada masyarakat yang dicita-citakan. Dan menurut Carl Friedrich, Kebijakan Publik adalah suatu arah tindakan yang diusulkan oleh seseorang, kelompok atau pemerintah dalam suatu lingkungan tertentu yang memberikan hambatan-hambatan dan kesempatankesempatan terhadap kebijakan yang diusulkan untuk menggunakan dan mengatasi dalam rangka mencapai suatu tujuan atau merealisasikan suatu sasaran atau maksud tertentu. Artinya Kebijakan Publik adalah standart yang dibuat oleh administrator Negara atau administrator publik. Jadi, Kebijakan Publik dapat dikatakan juga sebagai suatu proses kerja yang dapat dimanfaatkan untuk memperbaiki atau mengubah keadaan yang tidak berjalan sesuai aturan dalam pemerintah [4]. 
Pada kenyataannya masih terjadi pelanggaran lalu lintas yang ditemukan di kawasan Zero Point Kota Manado, dalam hal ini berkaitan dengan teknis Pelaksanaan maupun teknis Perlengkapan. Dalam pelaksanaan atau implementasi, membahas tentang manajemen lalu lintas tidak luput dari implementasinya sehingga dari pelaksanaan berlalu lintas yang diterapkan disetiap titik jalan raya bisa berjalan sesuai aturan yang ada, tetapi dapat juga memiliki kendala. Mazmanian dan Sabatier dalam (Wahab, 2001:17) yaitu Implementasi Kebijakan adalah pelaksana keputusan kebijakan dasar, biasanya dalam bentuk undangundang, namun dapat pula berbentuk perintahperintah atau keputusan eksekutif yang penting atau badan peradilan lainnya, keputusan mengidentifikasikan masalah yang ingin diatasi, menyebutkan secara tegas tujuan atau sasaran yang ingin dicapai dengan berbagai cara untuk menstruktur atau mengatur proses implementasinya. Dikaitkan dalam permasalah lalu lintas yang terjadi, maka dalam pelaksanaan lalu lintas harus diidentifikasi secara lengkap permasalahan apa yang harus diatasi yang menyangkut permasalahan kebijakan lalu lintas.

Jadi tahapan Implementasi merupakan peristiwa yang berhubungan dengan apa yang terjadi setelah suatu perundang-undangan ditetapkan dengan memberikan otoritas pada suatu kebijakan dengan membentuk output yang jelas dan dapat di ukur, dengan demikian tugas implementasi kebijakan sebagai suatu penghubung yang memungkinkan tujuan-tujuan kebijakan mencapai hasil melalui aktivitas atau kegiatan dan program pemerintah [5]. Demikian proses implementasi sebagai suatu praktek berdasarkan kebijakan yang telah dibuat.

Terkait dengan aturan yang ada, permasalahan ketertiban lalu lintas yang terjadi di kawasan Zero Point Kota Manado berpengaruh bagi aturan yang telah ditetapkan sehingga apa yang menjadi ketetapan dalam aturan dalam hal ini UU No 22 Tahun 2009 Lalu Lintas dan Angkutan Jalan, Pasal 1 Angka 32 mengemukakan bahwa: lalu lintas merupakan suatu keadaan berlalu lintas yang berlangsung secara teratur sesuai dengan hak dan kewajiban setiap pengguna jalan [6]. Dalam hal ini Seluruh pengguna jalan memiliki kewajiban untuk mentaati peratuan berlalu lintas. UU Lalu Lintas mengatur tentang cara berlalu lintas dengan tertib sehingga setiap pengguna jalan bisa dengan caranya masing-masing melahirkan disiplin berlalu lintas di jalan raya.

\section{Dalam PP No 37 Tahun 2017 tentang} Keselamatan Lalu Lintas dan Angkutan Jalan Pasal 15 angka 4 menyatakan bahwa: Penegakan hukum ketentuan persyaratan keselamatan berlalu lintas provinsi, kabupaten/kota paling sedikit dilakukan terhadap pelanggaran: a). persyaratan keselamatan jalan; b). tata cara berlalu lintas; c). persyaratan mengemudi; d. persyaratan teknis dan laik jalan; e). tata cara 
muat [7]. Dikaitkan dengan permasalahan lalu lintas yang sering terjadi maka dalam regulasi ini harus membekali masyarakat dalam berlalu lintas. Peraturan Walikota Manado No 53 Tahun 2016 tentang Kedudukan Susunan Organisasi, Tugas dan Fungsi Serta Tata Kerja Dinas Perhubungan, dalam pasal $13 \mathrm{~g}$ : Melaksanakan pembinaan keteriban dan disiplin lalu lintas di jalan, dan pasal 23 i: Melaksanakan operasi dan penertiban terhadap kendaraan-kendaraan yang parkir dan atau mengganggu kelancaran arus lalu lintas di wilayah area parkir [8]. Berdasarkan peraturan yang tersedia khususnya bagi Kota Manado yaitu mengatur tentang tata tertib lalu lintas serta tupoksi petugas lapangan dalam melaksanakan tugas lapangan, hal ini merupakan upaya pemerintah kota dalam menyikapi arus lalu lintas.

Dalam pembahasan ini teori yang dipakai untuk menganalisis lebih spesifik terkait permasalahan lalu lintas yang terjadi di kawasan zero point Kota Manado menggunakan teori dari Wiliam Dunn tentang Analisis Kebijakan yaitu disiplin ilmu sosial terapan yang menerapkan berbagai metode analisis, dalam konteks argumentasi untuk menciptakan informasi yang relevan. Metode analisis: Definisi, Prediks, Preskripsi, Deskripsi, Evaluasi. Proses: Merumuskan masalah, Peramalan masa depan kebijakan, Rekomendasi kebijakan, Pemantauan hasil kebijakan, Evaluasi kinerja kebijakan. Permasalahan lalu lintas sudah terjadi sejak lama, bahkan dampak di zaman modern saat ini bisa lebih buruk dibanding sebelumnya. Ditinjau dari berbagai aspek yang ada yaitu antara lain aspek pertumbuhan kendaraan setiap tahunnya maupun aspek pertumbuhan masyarakat yang dapat mempengaruhi situasi dan kondisi setiap tahunnya. Menurut Patton dan Savicky proses analisis kebijakan merupakan evaluasi alternatif kebijakan dari sisi: Teknis, Ekonomi, Politik [3]. Dikaitkan dengan implementasinya. Dalam proses analisis kebijakan adalah bagaimana mencari tahu sesuatu berdasarkan fakta yang ditemukan dilapangan, kemudian mengidentifikasi berbagai aspek permasalah untuk ditelusuri lebih spesifik terkait permasalahan, situasi, maupun kondisi lapangan. Hal ini dapat melahirkan hasil berdasarkan data yang di ditemui dilapangan. Menyangkut permasalahan lalu lintas yang terjadi maka proses analisis kebijakan sangat bermanfaat jika dikaitkan dalam permasalahan lalu lintas.

Demikian temuan yang didapat oleh peneliti berdasarkan Konsep Analisis kebijakan menurut William Dunn/ Patton dan Savicky yaitu dari empat indikator yang berkaitan [3]:

\section{a. Peramalan Masa Depan Kebijakan}

Masa depan kebijakan bermanfaat untuk setiap perubahan sistem yang ada, maka karena itu perlu diadakan peramalan atau melakukan suatu prediksi dalam membentuk proses kebijakan untuk kedepannya sebelum dilakukan, tentunya dengan pertimbangan-pertimbangan 
yang ada sehingga diharapkan kebijakan itu ketika ditetapkan dan diimplementasikan bisa berjalan dengan baik sesuai harapan bersama.

Dalam hal ini temuan yang di dapat yaitu Sopir angkutan kota dan masyarakat tahu bahwa ada aturan lalu lintas tetapi mereka kurang memahami isi aturannya seharusnya wajib di pahami terutama pengendara, dalam hal ini menjadi suatu hal yang serius mengingat banyak pelanggaran yang terjadi dikarenakan kurangnya pemahaman-pemahaman tentang aturan lalu lintas yang ada sebagai bekal berkendara, Materi yang disosialisasikan stidak dapat dipahami dengan baik oleh para sopir angkutan, Titik kawasan Zero Point masih kerap terjadi pelanggaran-pelanggaran lalu lintas yang disebabkan oleh pengemudi angkutan umum dan pengendara lainnya.

Dari hasil yang didapat peneliti menemukan adanya masyarakat yang tidak mengetahui aturan-aturan lalu lintas. Memang dapat dipahami untuk mengetahui aturan-aturan itu adalah masalah pribadi yang tidak dapat dipaksakan, tetapi sebagai pengguna jalan menjadi keharusan untuk mengetahui serta mentaati peraturan yang berlaku untuk ketertiban lalu lintas di Kota Manado khususnya di kawasan Zero Point. Aturan menjadi acuan bagi pengendara pada umumnya untuk mencegah dampak buruk terjadi dalam berlalu lintas serta menjaga ketertiban berlalu lintas sehingga terhindar dari kemacetan yang tidak wajar dan kecelakaan dalam melintasi jalan raya khususnya kawasan Zero Point.

\section{b. Pemantauan Hasil Kebijakan}

Dalam proses kebijakan sangat diperlukan pemantauan khusus untuk meninjau apakah kebijakan itu berjalan dengan baik atau sebaliknya, oleh sebab itu perlu diadakan proses pemantauan hasil dari kebijakan itu setelah ditetapkan dan atau sementara diimplementasikan.

kurangnya kinerja dari petugas lapangan dapat berpengaruh bagi kebijakan lalu lintas dalam hal ini bagian monitoring untuk memantau serta mengawasi kendaraankendaraan maupun masyarakat yang sering melakukan pelanggaran, serta dalam hal ini kurangnya ketegasan pengambilan keputusan bagi Dishub untuk menindak pengendara pengguna jalan yang sering melakukan pelanggaran dalam berlalu lintas, sehingga dari semua aspek yang didapat, bisa mempengaruhi proses kebijakan lalu lintas yang telah ditetapkan dalam UU No 22 Tahun 2009 tentang Lalu Lintas dan Angkutan Jalan [6], dan Perwako No 53 tahun 2016 tentang Tupoksi dan tata kerja Dishub Manado [8].

Petugas lapangan yang belum di nilai baik oleh masyarakat terkait pengawasan serta pamantauan lalu lintas, tentunya hal ini dapat dikatakan lalai dalam menjalankan tugas, Cara petugas mengambil ketegasan dalam penindakan 
pelanggaran belum menemukan pengaruh yang berdampak lebih bagi pengendara. sehingga dalam hal ini masih sering terjadi pelanggaran lalu lintas di kawasan zero point, Cara penyampaian informasi terkait kebijakan lalu lintas belum berpengaruh secara baik untuk membekali masyarakat pengguna jalan.

\section{c. Evaluasi Kinerja Kebijakan}

Evaluasi kinerja kebijakan merupakan tahap yang paling menentukan berjalan atau tidaknya proses kebijakan itu sendiri, dalam tahap evaluasi memang sangat diperlukan untuk mengoreksi suatu kinerja yang belum terlaksana dengan baik di lapangan, guna untuk merubah atau meningkatkan manfaat dari proses pelaksanaan kebijakan itu sendiri.

Data hasil temuan yang didapat yaitu Sering terjadinya pelanggaran lalu lintas dalam hal ini parkir liar atau berhenti secara sembarangan yang dilakukan oleh angkutan kota untuk menunggu penumpang. Tentunya dalam hal ini dititik yang tidak diperbolehkan, Petugas LLAJ yang belum bertugas dengan baik sesuai tupoksi yang sudah ditetapkan, Kinerja yang selalu di evaluasi tetapi belum menghasilkan perkembangan dan perubahan dalam arus lalu lintas.

masalah-masalah lalu lintas, salah satunya adalah pelanggaran parkir liar atau angkutan kota yang menunggu penumpang di lokasi yang tidak diperbolehkan. Hal itu kemudian menunjukan masih cukup banyak masalahmasalah yang harus diperbaiki dalam sistem kebijakan lalu lintas, dalam hal ini di kawasan zero point Kota Manado.

\section{d. Teknis}

Fokus utama adalah keamanan dan efisiensi debit lalu lintas, geometri jalan, trotoar, petunjuk penyeberangan, lampu lalu lintas, dan halte. Teknis lalu lintas berhubungan dengan bagian fungsional dari sistem transportasi atau perlengkapan yang disediakan

Dari temuan yang didapat yaitu Fasilitas teknis perlengkapan yang belum lengkap dan kesadaran masyarakat dalam berlalu lintas masih belum baik, sehingga sering kedapatan terjadinya perusakan marka jalan, dan selalu mengabaikan rambu-rambu lalu lintas yang ada di kawasan Zero Point, Dinas Perhubungan Kota Manado mengakui Belum sepenuhnya memperhatikan keadaan teknis perlengkapan yang ada dikawasan Zero Point, karena mempertimbangkan dana dan keadaan lalu lintas yang sering bermasalah, Masih belum tertibnya pengguna jalan akibat kurangnya teknis perlengkapan yang menjadi kebutuhan dalam kawasan Zero Point kota manado. Tentunya hal ini mempengaruhi keadaan arus lalu lintas yang dapat menimbulkan kemacetan.

fasilitas teknis yang belum lengkap, serta pelanggaran yang kerap kali dilakukan oleh masyarakat pengguna jalan membuat suatu 
keadaan lalu lintas di kawasan zero point menjadi tidak tertib.

\section{PENUTUP}

Hasil penelitian menunjukkan bahwa:

1. Aturan menjadi sangat penting bagi setiap pengguna jalan maka hasil yang didapat menunjukan kurangnya pemahaman masyarakat terkait aturan lalu lintas, oleh sebab itu aturan lalu lintas sangat diperlukan bagi setiap masyarakat secara umum untuk membekali masyarakat dalam berlalu lintas baik itu pengendara secara umum maupun penjalan kaki.

2. Proses sosialisasi adalah cara untuk membahas suatu kepentingan umum terkait sarana prasarana maupun kebijakan lalu lintas, maka berdasarkan hasil yang didapat menunjukan bahwa proses sosialisasi belum berjalan dengan baik sehingga mengakibatkan kurangnya pemahaman tentang aturan serta sarana prasarana lalu lintas bagi sopir angkutan umum.

3. Pengawasan dan pemantauan menjadi sangat penting untuk menyelidiki persoalan yang kerap terjadi dalam arus lalu lintas, dalam penelitian ini ditemukan hasil yang belum sesuai dengan tuposi bagi petugas lapangan, hal ini menunjukan bahwa fungsi pengawasan belum menunjukan suatu peningkatan yang kuat dikarnakan masih sering terjadi pelanggaran arus lalu lintas yang seringkali tidak diketahui petugas.

4. Pelanggaran lalu lintas seharusnya bisa ditindak dengan tegas sehingga masyarakat yang melanggar tidak melakukan pelanggaran yang sama kembali, tetapi dari hasil penelitian yang didapat cara petugas lapangan dalam memberikan pembinaan terkait masyarakat yang melanggar masih belum menunjukan suatu perubahan sehingga didapati masih banyak pelanggaran lalu lintas yang terjadi bahkan dengan unsur kesengajaan.

5.Angkutan kota menjadi kebutuhan bagi masyarakat pengguna jalan dalam beroperasi hal ini terlihat dalam kawasan Zero Point Kota Manado tetapi dari hasil yang didapat menunjukan bahwa angkutan kota sering melakukan pelanggaran berupa berhenti atau parkir secara sembarangan.

6. Teknis perlengkapan memiliki peran yang cukup penting dalam melengkapi jalan raya, sehingga dalam hal ini menjadi suatu kebutuhan juga sebagai petunjuk bagi pengendara jalan raya maupun penjalan kaki secara umum, dalam hasil yang didapat menunjukan kurangnya teknis perlengkapan mempengaruhi suasana arus lalu lintas menjadi tidak tertib, diataranya kurangnya indikator penyebrangan jalan bagi penjalan kaki dan halte untuk tempat berhenti bagi angkutan umum. 
7. Kesadaran masyarakat penjalan kaki dalam berlalu lintas dapat mempengaruhi suasana ketertiban lalu lintas, dari hasil penelitian di kawasan Zero Point Kota Manado menunjukan bahwa masyarakat penjalan kaki kebanyakan belum menunjukan kesadaran untuk tertib dalam melintasi jalan sehingga hal ini dapat berpengaruh bagi kelancaran arus lalu lintas dan hal ini bisa memicu kemacetan.

\section{Saran}

1. Diharapkan Pemerintah dapat lebih memperhatikan keadaan teknis pelaksanaan maupun, teknis perlengkapan lalu lintas di kawasan Zero Point Kota Manado, 2. Sanksi yang ada kiranya dipertegas oleh pemerintah sehingga dapat mencegah pelanggaran lalu lintas yang sering terjadi, 3. Diharapkan pemerintah selalu mengevaluasi dan bertindak dengan cepat terkait kebutuhan perlengkapan yang diperlukan di Kawasan Zero Point, 4. Dalam pelaksanaan sosialisasi diharapkan bisa lebih baik lagi sehingga masyarakat yang terlibat dapat memahami aturan berlalu lintas, 5. Diharapkan masyarakat pengguna jalan baik pengendara maupun penjalan kaki, agar bisa memiliki kesadaran tentang aturan-aturan dan inisiatif yang baik dalam melintasi jalan raya.

\section{UCAPAN TERIMA KASIH}

Terimakasih disampaikan kepada semua pihak yang boleh membanti dalam pelaksaan penelitian sehingga artikel ini dapat diselesaikan.

\section{REFERENSI}

[1] Abdul wahab, solichin. 2001. Analisis kebijakan dari formulasi ke implementasi kebijakan negara. Edisi kedua. Jakarta: bumi aksara

[2] Nugroho, riant. 2014. Public policy. Jakarta: PT. Elex media komputindo

[3] Patton, carl, V dan david S. Sawicki.1993. basic methods of policy analys and Planning. Prentice hall upper saddle river N.J 07458.

[4] Riant Nugroho. 2017. Public Policy Edisi Keenam, 2017: PT Elex Media Kompotindo Kelompok Gramedia Jakarta Anggota IKAPI, Jakarta

[5] Tangkilisan. 2003. Implementasi kebijakan publik. Yogyakarta: lukman offset

[6] Undang-Undang No 22 Tahun 2009 tentang Lalu Lintas dan Angkutan Jalan. 
Jurnal Kajian Kebijakan dan Ilmu Adminiatrasi Negara (JURNAL ADMINISTRO) Vol 1 No. 2 Desember 2019

P ISSN: 2714 - 6413 E ISSN: $2714-6421$

http://ejournal.unima.ac.id/index.php/administro

[7] Peraturan Pemerintah No 37 Tahun 2017

tentang Keselamatan Lalu Lintas dan

Angkutan Jalan.

[8] Peraturan Walikota Manado No 53 Tahun

2016 tentang Kedudukan Susunan

Organisasi, Tugas dan Fungsi Serta Tata

Kerja Dinas 